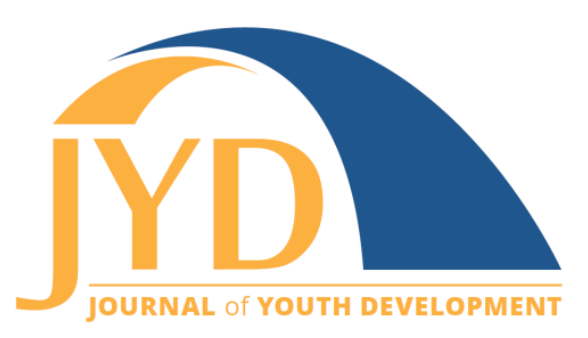

http://jyd.pitt.edu/ | Vol. 15 Issue 1 DOI 10.5195/jyd.2020.930 | ISSN 2325-4017 (online)

\title{
The Youth Development Workforce: The People, the Profession, and the Possibilities
}

\author{
Lynne M. Borden \\ University of Minnesota \\ Imborden@umn.edu \\ Michael Conn \\ Student Research Foundation \\ michaelconn.ny@gmail.com \\ Casey D. Mull \\ University of Georgia Extension \\ mullcd2@uga.edu \\ Michele Wilkens \\ NAA Board of Directors \\ michelewilkens1@gmail.com
}

\begin{abstract}
Understanding the role of youth workers and promoting an accurate representation of these professionals and their work requires a focus on current research, practice, and policies that capture the challenges and opportunities of the youth development workforce. An overview of this special issue of the Journal of Youth Development examines efforts to support individual youth workers, strategies organizations use to prepare and assist youth workers, and system approaches to building the capacity of the workforce in key areas such as quality and social emotional learning, and concludes with an encapsulation of interviews with 10 key leaders nationwide. They identified the overarching task as one of identification of the elements that can make the field cohesive across the different settings and programs, while supporting youth in their growth through experiences that are rooted in the science of learning and development. Finally, this special issue offers the opportunity to better understand the youth workers, examine different types of professional development pathways, explore the role that systems can play in support of these workers, and reflect on the challenges and opportunities raised by key leaders in the profession.
\end{abstract}

Key words: youth worker, youth professional, workforce, youth development, youth programs

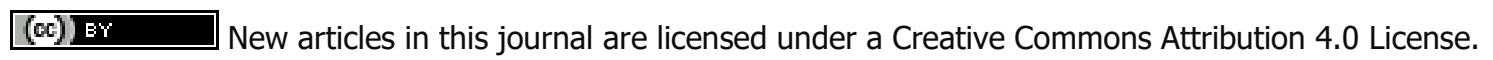
This journal is published by the University Library System, University of Pittsburgh and is cosponsored by the University of Pittsburgh Press. The Journal of Youth Development is the official peer-reviewed publication of the National Association of Extension 4-H Youth Development Professionals and the National AfterSchool Association. 


\section{Youth Development Workforce}

\section{Introduction}

The field of youth development is both broad and diverse. Serving young people from early elementary through young adulthood in a variety of roles, youth development professionals may function as after-school program staff, camp counselors, coaches, teen shelter staff, caseworkers, faith-based youth program staff, and other roles across a wide variety of schooland community-based settings in programs that occur after school, on weekends, and during the summer offered by a diverse set of public, non-profit, and for-profit organizations. This diversity of ages served, types of work, settings, and sponsors often challenges the field to define the role of the youth worker (Cooper, 2018). Pozzoboni and Kirshner (2016) note, "there is a curious lacuna, however, when it comes to the profession of youth work in the United States. Unlike K-12 classroom teaching, a profession with longstanding-if contestedlegitimacy and recognition, "youth work" does not call forth familiar imagery or cultural narratives" (p. 2).

In an attempt to better understand the role of youth workers and promote accurate representation of these professionals and their work, this special issue of the Journal of Youth Development focuses on current research, practices, and policies that capture the challenges and opportunities of the youth development workforce. Volunteers are not part of this special issue; a companion special issue will focus on the important role of volunteers, who are often the cornerstone of many youth development programs. Articles within this special issue examine efforts to support individual professionals, strategies organizations use to prepare and assist youth workers, and system approaches to building the capacity of the workforce in key areas such as quality and social emotional learning, and concludes with an encapsulation of interviews with ten key leaders nationwide. Their responses offer insights on compelling topics, including the greatest opportunities and challenges facing the systems that support youth workers and efforts towards national youth work policies and goals.

\section{Understanding Youth Work and the Essential Youth Worker}

Youth workers are the linchpin within a youth program, making the difference in whether or not youth programs are successful. Youth workers individually and collectively must have the skills and knowledge needed to design, successfully implement, manage, and evaluate programs. This includes building quality relationships with the young people who attend, understanding the types and quality of programs to be delivered, establishing settings that are both physically and psychologically safe, supporting skill development that is appropriate for participants' 


\section{Youth Development Workforce}

developmental level, and providing opportunities for youth to be actively engaged in determining the focus of the program (Eccles \& Gootman, 2002; Hurd \& Deutsch, 2017). A youth worker's role is one of significant importance, and "program success is dependent on the skills and competencies" of youth workers (Vandell \& Lao, 2016, p. 52). Given this key role, it is important to consider how youth workers are empowered in the work they do, as young people receive the greatest benefit when the adults who facilitate their programs are well prepared and supported (Deutsch, 2017; Garst, Weston, Bowers, \& Quinn, 2019). In sum, youth workers' knowledge, skills, experience, and expertise determine the quality of and ways in which programs are developed, managed, and evaluated. It is through high-quality programs that positive interactions between staff and youth occur, affording essential benefits to the young people who participate. The articles in this special issue focus on the important role of and supports for youth workers.

\section{Youth Worker Beliefs, Stressors, and Supports}

This issue focuses on the people involved in paid youth work. In the article, Sustaining Passion: Findings from an Exploratory Study of the OST Program Workforce, Hall, DeSouza, Starr, Wheeler, and Schleyer describe an exploratory study of the out-of-school-time workforce, where the workforce identified "building relationships with and fostering positive and healthy development for children" (p. 20) as the most important issue. In Camp Organizational Support for Creativity Among New and Returning Camp Counselors, Lynch, Hartman, Trauntvein, and Moorhead provide an understanding of the importance of supporting creativity among youth workers for successful summer camps. As the authors note, "Satisfied employees, who are supported in their creativity, have increased performance, motivation, and commitment" (p. 24). The article Understanding Youth Worker Job Stress explores what contributes to job stress for youth workers. White, DeMand, McGovern, and Akiva present findings from their randomized controlled trial study of professional development intervention, including, "one individual resource that may ameliorate OSL staff stress is supervisor support" (p. 60). These articles offer important insights into the individuals who choose to be youth workers, what matters to them personally and professionally, and the kinds of supports that can be effective for them.

\section{Youth Worker Preparation}

Given the importance of the role of youth workers in enhancing a young person's positive development, it is critical that those in this role have the knowledge and skills to implement 


\section{Youth Development Workforce}

programs and practices successfully. Several articles explore formal and informal learning systems designed to prepare and support youth workers. Robideau and Santl, in their article entitled, Youth Work Matters: Online Professional Development for Youth Workers, offer insights into the development of online non-credit, cohort-based professional development opportunities. They indicate, "Youth workers appreciate the convenience as well as the interactions with other professionals from a variety of organizations and locations" (p. 77). Shanahan and Sheehan's article, Creating Community through Cohort Learning: A Training Model for Youth Development Professionals, offers a discussion of how a cohort-learning model supports the onboarding of staff in ways that are consistent, tangible, and lend to professional relationships. Moreover, they note, "Cohorts enhance professional youth worker relationships and foster a learning community through networking and collaborative activities, influence professional relationship building through the sharing of applicable skills and theory, and provide a [Community of Practice] to discuss ideas and share resources" (p. 91).

Wilkens, in her national study, Employee Churn in After-School Care: Manager Influences on Retention and Turnover, identifies the pivotal role of managers' mindset in retaining afterschool program leaders and staff. Wilkens details how challenging managers' helplessness and creating organizational goals, actionable data, feedback loops, and accountability significantly decreased after-school employee turnover. In Preparing Capable Youth Workers: The Project Youth Extension Service Approach, Silliman, Edwards, and Johnson share details of a preservice training and practice experience for college students as well as outcomes for these youth workers. They note, "Those new to youth development especially need to become competent in what to do and how to think to create a climate for PYD" (p. 136). Finally, Quinn, Garst, Bowers, and Weston describe an academic program in their article, Advancing Academic Pathways for Building Capacity in the Youth Development Profession, offering insights into a graduate level academic degree program and the importance of preparing youth workers through a learning structure that promotes the field of youth development. They found that "outcomes delineated the likelihood of strengthening the youth development workforce utilizing academic institutions and online learning technologies" (p. 160). To summarize, the professional development of youth workers is conducted in both formal and informal settings, and some promising practices are discussed. However, there are no agreed upon standards or criteria for preparing youth workers, revealing an area that warrants further study and development. 


\section{Youth Development Workforce}

\section{Systemic Supports for Youth Workers}

Addressing the needs of individual youth workers is critical for the success of programs; however, systems-level support and functionality are equally important to empowering workers with the resources they need to succeed and to enhance the positive impact and long-term viability of youth-serving organizations. These systemic considerations include understanding retention of youth workers in a field that can be demanding, often with low wages, long work hours, and limited benefits, yielding staff turnover as one of the greatest challenges programs face. Creating a Rising Tide: Improving Social and Emotional Learning Across California offers a description of a field-building initiative that includes statewide strategies to increase an individual workers' knowledge, skills, and understanding of social-emotional learning. Vance and Goldberg state, "California's strategy brings together research and practical wisdom. It acknowledges that the success of young people hinges on our ability to equip the expanded learning workforce to nurture young people's social, emotional, and academic development" ( $p$. 177).

Richmond, Sibthorp, and Bialeschki offer insights into employing youth camp workers in their article, Motivations and Barriers for Seasonal Camp Employment. Their nationally representative study identifies motivators in the retention of youth camp workers. They found, "Among returning camp staff, perceived job impact and camp embeddedness were the primary drivers of retention and these factors were more important than compensation" (p. 200). In their article entitled, Betting on the Workforce: An Interview With the S. D. Bechtel, Jr. Foundation, Moroney and Young share experiences from that foundation's work on developing adult practices and youth character development.

Given the importance of well-prepared youth workers, the assessment of program quality becomes paramount, as it serves as a central indicator of a program's strengths and weaknesses and the impact of workers on youth. In the article, Building Collective Capacity for Program Quality Improvement: Boston Beyond's Certified Observer Network, Dodge outlines the use of the National Institute on Out-of-School Time (NIOST) Assessment of Program Practices Tool (APT) to evaluate 19 dimensions of program quality through observation. Dodge notes, "The vast majority of respondents attest that the certified observer experience improved their understanding of program quality and exposed them to new program practices" (p. 232). Newman, in her article entitled, Supporting the Out-of-School Time Workforce in Fostering Intentional Social and Emotional Learning, identifies the importance of integrating socialemotional practices at an organizational level, as well as throughout the programmatic practices 


\section{Youth Development Workforce}

of youth workers. To encapsulate, youth workers need systems in place that can provide high quality support and opportunities to them as individuals as well as to the programs they serve. Taken together, these articles on systemic supports for youth workers offer various ways the field can elevate youth workers skills, competencies, retention, and satisfaction.

\section{Key Leader Insights}

In this issue's concluding article, Foundations for the Future: Building an Integrated, Cohesive Field of Youth Development, Borden and colleagues present the ideas and reflections of 10 key leaders in the field of youth development, who were selected for their contributions to the field. Respondents completed a short questionnaire regarding the current condition and the future of the field of youth workers. They offer insights into work that is currently happening within the field, challenges that face organizations that serve young people, and possibilities for the future. As Pam Garza, private consultant states, "With youth as the most significant asset any nation can have, one of the greatest challenges facing the systems that support youth workers remains an attitude and culture towards the significance of this work" (p. 274). Moreover, several of the key leaders noted that the field of youth development is fragmented, and individuals who serve in different roles (e.g., camp counselor, youth homeless shelter staff, and others) do not recognize the work they do as youth work. Karen Pittman, President and CEO of the Forum for Youth Investment, stated that youth "are never well-served by fragmented approaches" (p. 273). The field is full of potential and challenges as it moves forward. The overarching task is to identify and draw out the elements that can make the field cohesive across the different settings and programs, while supporting youth in their growth through experiences that are rooted in the science of learning and development.

In conclusion, this special issue offers readers the opportunity to better understand the youth worker as an individual who works in youth programs, examine different types of professional development pathways that exist both in formal and informal settings, explore the role that systems can play in support of these workers, and reflect on the challenges and opportunities raised by key leaders in the profession. This special issue identified key points needing further study and action to drive the field of youth work toward coherence and maximum effectiveness. To move the field much more needs to be done. 
Journal of Youth Development | http://jyd.pitt.edu/ | Vol. 15 Issue 1 DOI 10.5195/jyd.2020.930

Youth Development Workforce

\section{References}

Borden, L., Ballard, J., Michl-Petzing, L., Conn, M., Mull, C. D., \& Wilkens, M. (2020). Foundations for the future: Building an integrated, cohesive field of youth development. Journal of Youth Development, 15(1), 266-286. https://doi.org/10.5195/jyd.2020.937

Cooper, T. (2018). Defining youth work: Exploring the boundaries, continuity and diversity of youth work practice. In P. Allred, F. Cullen, K. Edwards, \& D. Fusco (Eds.), The SAGE handbook of youth work practice (pp. 3-17). London, UK: Sage.

Deutsch, N. L. (2017). Executive summary. In N. L. Deutsch (Ed.), After-school programs to promote positive youth development: Integrating research into practice and policy (pp. ix-x). Cham, Switzerland: Springer. https://doi.org/10.1007/978-3-319-59132-2

Dodge, E. (2020). Building collective capacity for program quality improvement: Boston Beyond's certified observer network. Journal of Youth Development, 15(1), 220-238. https://doi.org/10.5195/jyd.2020.818

Eccles, J. S., \& Gootman, J. A. (2002). Community programs to promote Youth Development. Washington, DC: National Academies Press.

Garst, B. A., Weston, K. L., Bowers, E. P., \& Quinn, W. H. (2019). Fostering youth leader credibility: Professional, organizational, and community impacts associated with completion of an online master's degree in youth development leadership. Children and Youth Services Review, 96, 1-9. https://doi.org/10.1016/j.childyouth.2018.11.019

Hall, G. (2020). Sustaining passion: Findings from an exploratory study of the OST program workforce. Journal of Youth Development, 15(1), 9-23. https://doi.org/10.5195/jyd.2020.821

Hurd, N., \& Deutsch, N. (Spring, 2017). SEL-focused after-school programs. The Future of the Children, $2 \pi(1), 95-115$.

Lynch, M. L., Hartman, C. L., Trauntvein, N. E., \& Moorhead, C. A. E. (2020). Camp organizational support for creativity among new and returning camp counselors. Journal of Youth Development, 15(1), 24-46. https://doi.org/10.5195/jyd.2020.795

Moroney, D. A., \& Young, J. (2020). Betting on the workforce: An interview with the S.D. Bechtel, Jr. Foundation. Journal of Youth Development, 15(1), 204-219.

\section{https://doi.org/10.5195/jyd.2020.815}

Newman, J. Z. (2020). Supporting the out-of-school time workforce in fostering intentional social and emotional learning. Journal of Youth Development, 15(1), 239-265. https://doi.org/10.5195/jyd.2020.807

Pozzoboni, K. M., \& Kirshner, B. (2016). The changing landscape of youth work: Theory and practice for an evolving field. In K. M. Pozzoboni \& B. Kirshner (Eds.), The changing landscape of youth work: Theory and practice for an evolving field (pp. 1-10). Charlotte, NC: Information Age. 
Journal of Youth Development | http://jyd.pitt.edu/ | Vol. 15 Issue 1 DOI 10.5195/jyd.2020.930

Youth Development Workforce

Quinn, W. H., Garst, B. A., Bowers, E. P., \& Weston, K. L. (2020). Advancing academic pathways for building capacity in the youth development profession. Journal of Youth Development, 15(1), 150-164. https://doi.org/10.5195/jyd.2020.814

Richmond, D., Sibthorp, J., \& Bialeschki, M. D. (2020). Motivations and barriers for seasonal camp employment. Journal of Youth Development, 15(1), 180-203. https://doi.org/10.5195/jyd.2020.822

Robideau, K., \& Santl, K. (2020). Youth work matters: Online professional development for youth workers. Journal of Youth Development, 15(1), 70-78. https://doi.org/10.5195/jyd.2020.820

Shanahan, A., \& Sheehan, T. (2020). Creating community through cohort learning: A training model for youth development professionals. Journal of Youth Development, 15(1), 79-93. https://doi.org/10.5195/jyd.2020.827

Silliman, B., Edwards, H. C., \& Johnson, J. C. (2020). Preparing capable youth workers: The project youth Extension Service approach. Journal of Youth Development, 15(1), 122-149. https://doi.org/10.5195/jyd.2020.824

Vance, F., \& Goldberg, R. (2020). Creating a rising tide: Improving social and emotional learning across California. Journal of Youth Development, 15(1), 165-179. https://doi.org/10.5195/jyd.2020.819

Vandell, D. L., \& Lao, J. (2016). Building and retaining high quality professional staff for extended education programs. International Journal for Research on Extended Education, 4(1), 52-64. https://doi.org/10.3224/ijree.v4i1.24775

White, A. M., DeMand, A., McGovern, G., \& Akiva, T. (2020). Understanding youth worker job stress. Journal of Youth Development, 15(1), 47-69. https://doi.org/10.5195/jyd.2020.817

Wilkens, M. (2020). Employee churn in after-school care: Manager influences on retention and turnover. Journal of Youth Development, 15(1), 94-121. https://doi.org/10.5195/jyd.2020.812 